\title{
A novel synthesis of 4-toluene 9H-carbazole-9-carbodithioate, electropolymerization and impedance study
}

\author{
M. Ates ${ }^{1 *}$, N. Uludag ${ }^{1}$, T. Karazehir ${ }^{1,2}$, F. Arican $^{1}$ \\ ${ }^{1}$ Department of Chemistry, Faculty of Arts and Sciences, Namik Kemal University, Degirmenalti Campus, 59030 \\ Tekirdag, Turkey \\ ${ }^{2}$ Department of Chemistry, Faculty of Arts and Sciences, Istanbul Technical University, Maslak, Istanbul, Turkey
}

Received 5 January 2014; accepted in revised form 8 March 2014

\begin{abstract}
A novel synthesis of 4-toluene 9H-carbazole-9-carbodithioate (TCzC) was chemically synthesized and characterized by Fourier Transform Infrared (FTIR), proton nuclear magnetic resonance ( $\left.{ }^{1} \mathrm{H}-\mathrm{NMR}\right)$, and carbon nuclear magnetic resonance $\left({ }^{13} \mathrm{C}-\mathrm{NMR}\right)$ spectroscopies. Specific $\left(C_{\mathrm{sp}}\right)$ and double layer capacitances $\left(C_{\mathrm{dl}}\right)$ of the electro-coated poly(carbazole) and poly $(\mathrm{TCzC})$ films were obtained on glassy carbon electrode (GCE) by impedimetric method with DC potential from -0.1 to $+1.0 \mathrm{~V}$ by increasing potential of $0.2 \mathrm{~V}$. The polymers were characterized by Cyclic voltammetry (CV), Fourier transform infrared reflectance-attenuated total reflection spectroscopy (FTIR-ATR), Atomic force microscopy (AFM), and Electrochemical impedance spectroscopy (EIS). The use of additional variable (DC potential) helped to disambiguate the equivalent circuit model of $R(C(R(Q(R W))))(C R)$. Simulation results were compared with experimental data. In this study, substituted group effects of $\mathrm{CS}_{2}$ and tosyl on carbazole polymer were investigated by EIS technique. $\mathrm{CS}_{2}$ group together with tosyl group in the structure of carbazole decreased the specific capacitance value $\left(C_{\mathrm{sp}}=0.43 \mathrm{mF} \cdot \mathrm{cm}^{-2}\right) \mathrm{com}-$ pared to $\mathrm{PCz}\left(C_{\mathrm{sp}}=1.44 \mathrm{mF} \cdot \mathrm{cm}^{-2}\right)$. Electropolymerization formation was seriously affected by substituted groups of $\mathrm{CS}_{2}$ and tosyl on conjugation system because of the electron donor and acceptor ability.
\end{abstract}

Keywords: coatings, functional polymer, electrochemical impedance spectroscopy, electropolymerization, conducting polymer

\section{Introduction}

Among conducting polymers, polycarbazoles are known for their good electro-activity $[1,2]$ and thermal [3-5], electrical [6], photo-physical [7], and electrochromic properties [8]. They have been suggested for a number of applications, such as electroluminescent devices [9], sensors [10,11], redox catalysts [12], and electrochromic displays [13]. The functional groups, such as amino, imino and sulfonic groups have been performed for achieving new polymers which meet the criteria of commercial applications [14-16]. There are many novel syntheses of functional polycarbazole papers. 3,6bis (2,3-dihydrothieno [3,4-b][1,4] dioxin-5-yl)-9tosyl-9H-carbazole [17], 5-(3,6-Dibromo- $9 H$-carbazole-9-yl)-pentane nitrile [18], 9-tosyl-9H-carbazole [19], 9-tosyl-9H-carbazole-co-pyrrole [20], $\mathrm{N}$-(1,4-Dimethyl-9H-carbazole-3-ylmethyl)- $N$-tosyl aminoacetaldehyde diethyl acetal [21], ethyl 4hydroxy-9-tosyl-9H-carbazole-3-carboxylate [22], 4-[2-carbazole-3-yl) vinyl] pyridium tosylate [23], $\mathrm{N}$-(o-ethynyl)phenylynamides and arylynamides [24] and 9-(4-nitrophenylsulfonyl)-9H-carbazole [25] were given in literature. The synthesis was per-

\footnotetext{
${ }^{*}$ Corresponding author, e-mail: mates@nku.edu.tr

(C) BME-PT
} 
formed especially with donor-acceptor group, which supported electron rich and poor region on the polymer skeleton [26].

Electrochemical impedance spectroscopy (EIS) is one of the most frequently used analytical tools for the characterization of capacitors or supercapacitors [27]. EIS is used to explain behavior of modified electrodes explaining two models, which are known as uniform [28] and porous medium [29]. In this study, porous medium was evaluated by EIS. At present, the electrode materials for supercapacitors have been widely investigated especially for carbon materials such as activated carbons, the mostly widely used electrode materials due to their large surface area, relatively good electrical properties and moderate cost [30-32]. Among the carbon materials, carbon nanotubes (CNT) are considered to be potential candidates as the electrodes in supercapacitor, due to their high accessible surface, chemical stability, excellent mechanical properties, good electrical conductivity, and unique pore structure $[33,34]$. The other electrode materials such as transition metal oxides and conducting polymer [35, $36]$ are being widely investigated to improve the specific capacitance and the energy density of supercapacitor [37, 38].

Herein, in this study, we principally synthesized $\mathrm{CS}_{2}$ and tosyl group of substituent of carbazole monomer and compare the effects of these functional groups on EIS properties. Also we investigated the equivalent circuit model of $R(C(R(Q(R W))))(C R)$ with Kramers-Kronig transform to fit the experimental and theoretical data. As a result, this paper presents a new approach of circuit Modeling and capacitive behavior of a novel polymer synthesis by using EIS technique.

\section{Experimental}

\subsection{Materials}

Carbazole (Alfa Aesar, USA), sodium hydroxide $(\mathrm{NaOH})$, carbon disulfide (Aldrich, USA), p-toluensulfonyl chloride (Aldrich, USA) were received without further purification. Dichloromethane $\left(\mathrm{CH}_{2} \mathrm{Cl}_{2}\right)$, dimethylsulfoxide (DMSO), diethyl ether, acetonitrile $\left(\mathrm{CH}_{3} \mathrm{CN}\right)$, tetraethylammonium tetrafluoroborate $\left(\mathrm{TEABF}_{4}\right)$ were supplied from Merck Chemical Co. (Germany) and they were used as received. Silica gel, used for synthesis experiments, was described as an efficient and reusable catalyst.

\subsection{Electrochemical tests}

Cyclic voltammetry (CV) was performed by using PARSTAT 2273, USA (software: powersuit and Faraday cage: BASI Cell Stand C3, West Lafayette, Indiana, USA) in a three electrode configuration, which employed glassy carbon electrode (GCE) (area: $0.07 \mathrm{~cm}^{2}$ ) as the working electrode, platinum wire as the counter electrode and $\mathrm{Ag} / \mathrm{AgCl}(3.5 \mathrm{M})$ as the reference electrode. All electrochemical experiments were carried out at $20 \pm 1^{\circ} \mathrm{C}$.

\subsection{Structure characterization}

Modified carbon fiber microelectrode (CFME) was characterized by Fourier transform infrared- attenuated total reflection (FTIR-ATR) spectroscopy (Perkin Elmer, Spectrum One B, with an universal ATR sampling accessory (4000-550 $\mathrm{cm}^{-1}$ ) with a diamond and ZnSe crystal, USA). The Atomic force microscopy (AFM) images were obtained with Park System XE100 Suwon, Korea. In all AFM analysis, the non-contact mode was employed by using Al coated high resonance frequency silicon tips (265$400 \mathrm{kHz}$ ) with $4 \mu \mathrm{m}$ thickness, $35 \mu \mathrm{m}$ mean width, $125 \mu \mathrm{m}$ length and $20-75 \mathrm{~N} / \mathrm{m}$ force constant. High resolution images $(1024 \times 1024$ pixels $)$ and the raw data were collected by the XEI image. Melting point was determined in a capillary tube on Electro thermal IA 9000 apparatus and uncorrected (Stone Staffordshire, UK). Mass spectra were determined by means of Agilent 5973 model of GC-MS (Santa Clara, CA, USA).

\subsection{Electrochemical impedance spectroscopy and modeling}

Electrochemical impedance spectroscopic (EIS) measurements were performed for $\mathrm{Cz}$ and $\mathrm{TCzC}$ in the initial molar concentration of $3.0 \mathrm{mM}$ in $0.1 \mathrm{M}$ tetraethylammonium tetrafluoroborate $\left(\mathrm{TEABF}_{4}\right) /$ dichloromethane $\left(\mathrm{CH}_{2} \mathrm{Cl}_{2}\right)$ - acetonitrile $\left(\mathrm{CH}_{3} \mathrm{CN}\right)$ volume ratio of (8:2). EIS measurements were done in monomer-free electrolyte solution with perturbation amplitude of $10 \mathrm{mV}$ and DC potential from -0.1 to $+1.0 \mathrm{~V}$ on glassy carbon electrode (GCE) over a frequency range of $0.01 \mathrm{~Hz}$ to $100 \mathrm{kHz}$ with PARSTAT 2273 model Potansiostat/galvanostat. All measurements began at the open circuit potential, modified polymer films were allowed to equilibrate for $\sim 10$ min at each potential before being measured. The equivalent circuit model of $R(C(R(Q(R W))))(C R)$ 
was taken by Kramers-Kronig Transform (ZSimpwin programme).

\section{Results and discussion \\ 3.1. Synthesis procedure}

A suspension of $\mathrm{NaOH}(1.2 \mathrm{~g}, 30$ mmoles $)$ in dimethylsulfoxide (DMSO, 150 mmoles) was prepared. Afterwards, carbazole (5 g, 29.9 mmoles) was added under vigorous stirring. The reaction mixture was stirred for 2 hours at room temperature. Carbondisulfide ( $2.2 \mathrm{~g}, 30$ mmoles) was added dropwise into the mixture, and the resultant reddish solution was stirred for 4 hours at room temperature, and then by adding slowly p-toluensulfonylchloride $(5.7 \mathrm{~g}, 30 \mathrm{mmoles})$ in DMSO $(30 \mathrm{~mL})$. The final mixture was stirred for a night. The resultant reaction mixture which was poured into large amount of water and yellow solid was obtained by filtration. The crude product was purified by silica gel chromatography and crystallised from diethyl ether. The resultant mass was $6.5 \mathrm{~g}$. 4-toluene $9 \mathrm{H}$-carbazole9-carbodithioate (yield: 59\%) was obtained at the melting temperature of $194^{\circ} \mathrm{C}$ and molecular weight of $337.53 \mathrm{~g} / \mathrm{mol}$ obtained by coupled gas chromatorgpahy and mass spectrometry (GC-MS) (Figure 1).

As a basis for the synthetic approaches to 4-toluene9H-carbazole-9-carbodithioate was synthesized from carbazole by using similar methods given in the literatures $[39,40]$. The spectra of dithiocarbamates obtained were identical to those of the produced in the above literatures.

$\mathrm{C}=\mathrm{S}$ bond on $\mathrm{CS}_{2}$ group connected with carbazole and electron pair on nitrogen atom showed a reso-
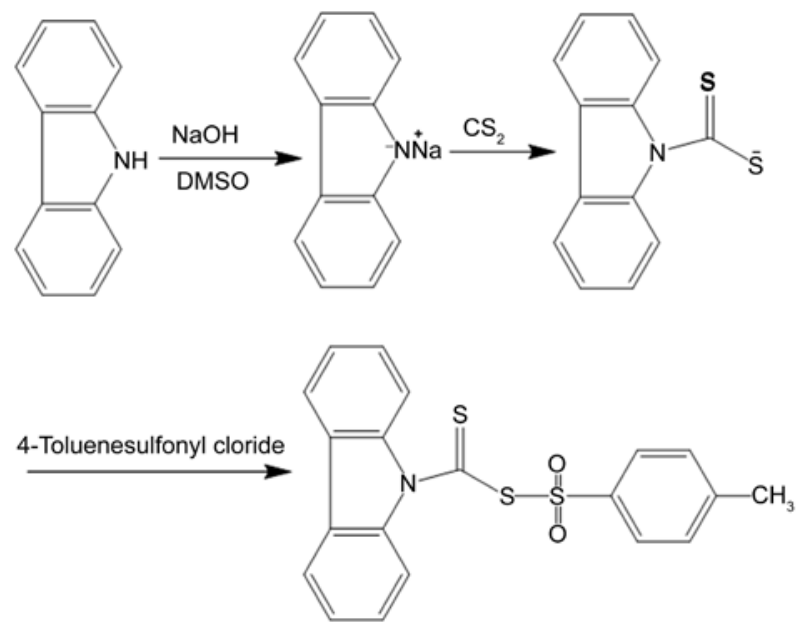

Figure 1. Synthesis procedure of 4-toluene $9 H$-carbazole9-carbodithioate
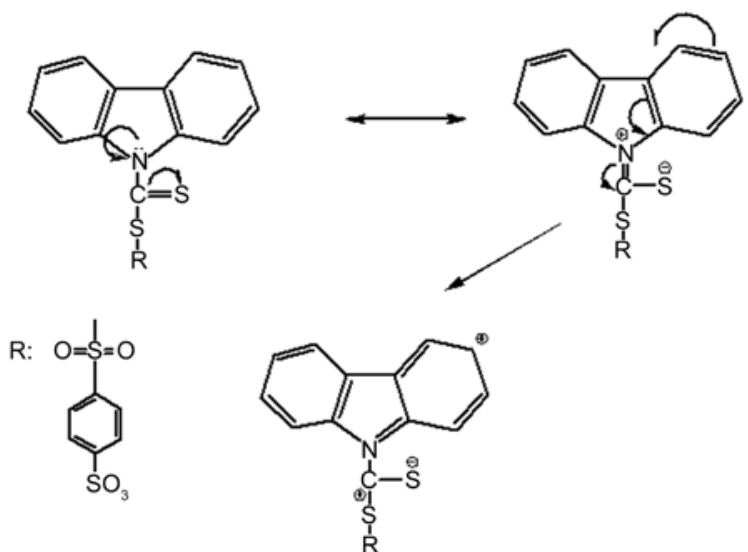

Figure 2. Resonance formation of 4-toluene $9 \mathrm{H}$-carbazole9-carbodithioate

nance structure and formed an active side with positive $(+)$ charges on the carbazole structure of 3 and 6 position. An easy polymer formation was supplied by cationic polymerization with conjugation system. Polymerization formation was crucially affected by substituted groups on conjugation system due to electron donor and acceptor groups as shown in Figure 2.

Carbazole was treated with $\mathrm{NaOH}$ and carbondisulfide in the presence of DMSO then added 4-methyl benzene-1-sulfonylchloride to obtain 4-toluene- $9 \mathrm{H}$ carbazole-9-carbodithioate (59\% yield). 4-toluene9H-carbazole-9-carbodithioate was determined by FTIR, ${ }^{1} \mathrm{NMR}$, and ${ }^{13} \mathrm{C}-\mathrm{NMR}$.

\subsection{Characterisation of 4-toluene \\ 9H-carbazole-9-carbodithioate monomer}

FT-IR analysis (potassium bromide): $v 3058 \mathrm{~cm}^{-1}$ (aromatic $\mathrm{C}-\mathrm{H}$ ), $1593 \mathrm{~cm}^{-1}$ (aromatic $\mathrm{C}=\mathrm{C}$ ), $1487 \mathrm{~cm}^{-1}$ (aromatic $\mathrm{C}=\mathrm{C}$ ), $1435 \mathrm{~cm}^{-1}$ (aromatic $\mathrm{C}=\mathrm{C}$ ). The peak of $\mathrm{N}-\mathrm{H}$ at $3000-3500 \mathrm{~cm}^{-1}$ was not observed in the FTIR spectrum. It proved the insertion of the $\mathrm{CS}_{2}$ group into the carbazole structure as shown in Figure 3.

${ }^{1} \mathrm{H}-\mathrm{NMR}$ (deuterochloroform) spectrum of TCzC: $\delta$ $2.31\left(\mathrm{~s}, \mathrm{CH}_{3}\right), 7.07-7.12(\mathrm{~d}, 2 \mathrm{H}$, aromatic $\mathrm{C}-\mathrm{H})$, 7.25-7.33 (d, 2H, aromatic C-H ), 7.35-7.41 (m, 2H, aromatic $\mathrm{C}-\mathrm{H}), 7.46-7.90(\mathrm{~m}, 2 \mathrm{H}$, aromatic $\mathrm{C}-\mathrm{H})$, 8.31-8.34 (d, 2H, aromatic $\mathrm{C} ; \mathrm{H})$. 4-toluene-9H-carbazole-9-carbodithioate was determined by NMR experiments and FT-IR spectroscopy. The most characteristic value of it ${ }^{1} \mathrm{H}-\mathrm{NMR}$ spectrum was a singlet of methyl proton peaks at $2.31 \mathrm{ppm}$, as well as between 7.07-7.90 ppm aromatic protons.

${ }^{1} \mathrm{H}-\mathrm{NMR}$ (deuterochloroform) spectrum of $\mathrm{Cz}: \delta$ 7.21-7.25 (m, 4H, aromatic $\mathrm{CH}), 7.39-7.51$ (m, 4H, 


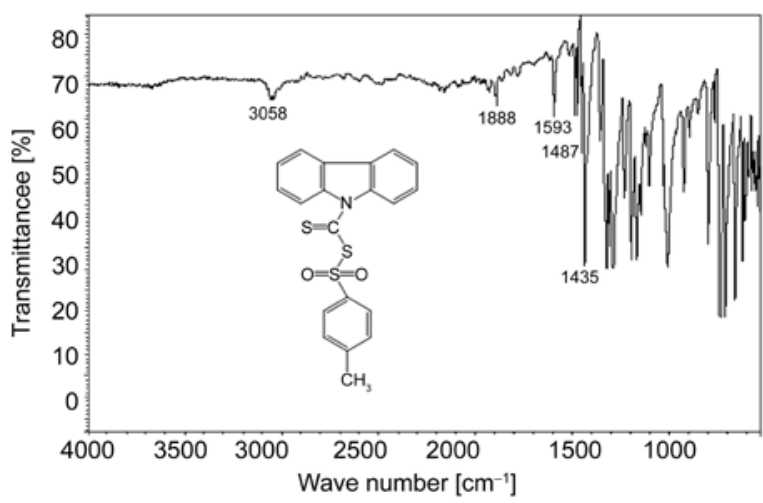

Figure 3. FTIR spectrum of 4-toluene $9 H$-carbazole-9-carbodithioate

aromatic $\mathrm{CH}), 8.09$ (s, $1 \mathrm{H}, \mathrm{NH}) .{ }^{1} \mathrm{H}-\mathrm{NMR}$ peak difference between $\mathrm{Cz}$ and $\mathrm{TCzC}$ can be easily obtained as shown in Figure 4.

${ }^{13} \mathrm{C}$ NMR (deuterochloroform): $\delta 194.85 ; 139.85$; $127.11 ; 126.14 ; 124.27 ; 120.37 ; 115.38 ; 77.34$; $77.22 ; 77.02 ; 76.70$. Analytically calculated for $\mathrm{C}_{20} \mathrm{H}_{15} \mathrm{NO}_{2} \mathrm{~S}_{3}$ (397.53 g/mol) : C (71.01); H (4.72);

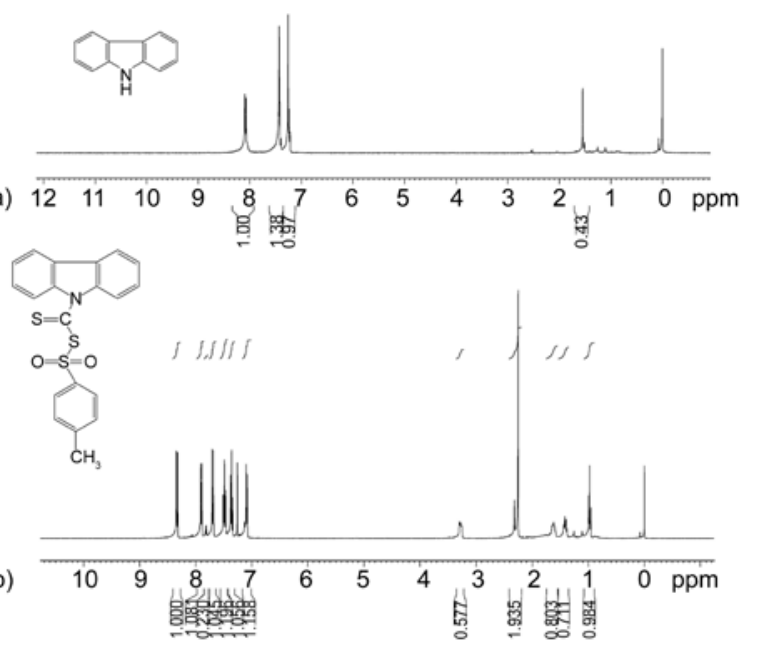

Figure 4. ${ }^{1} \mathrm{H}-\mathrm{NMR}$ spectra of a) $\mathrm{Cz}$ and b) $\mathrm{TCzC}$

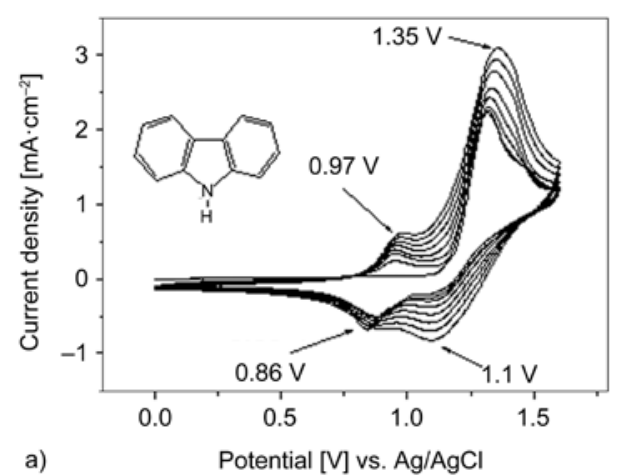

Figure 6. Cyclic voltammetry of a) $\left.\mathrm{Cz},[\mathrm{Cz}]_{0}=3.0 \mathrm{mM}(Q=6.128 \mathrm{mC}), \mathrm{b}\right) \mathrm{TCzC},[\mathrm{TCzC}]_{0}=3.0 \mathrm{mM}(Q=5.550 \mathrm{mC})$ on glassy carbon electrode (GCE) in $0.1 \mathrm{M} \mathrm{TEABF}_{4} / \mathrm{CH}_{2} \mathrm{Cl}_{2}-\mathrm{CH}_{3} \mathrm{CN}(8: 2), 8$ cycle, scan rate: $50 \mathrm{mV} \cdot \mathrm{s}^{-1}$, potential range: $0.0-1.8 \mathrm{~V}$

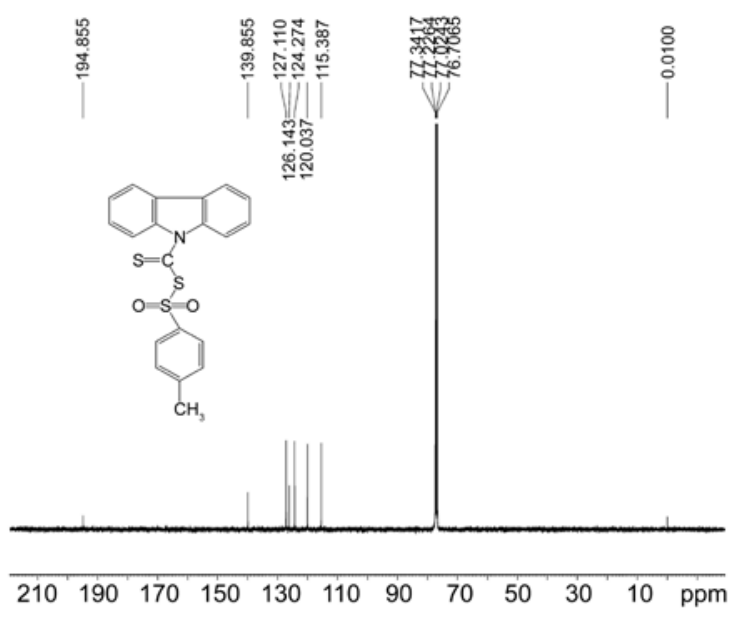

Figure 5. ${ }^{13} \mathrm{C}$-NMR spectrum of $\mathrm{TCzC}$

N (4.72); O (4.36). Found: C (71.04); H (4.76); N (4.32) (Figure 5).

\subsection{Electropolymerization of poly(4-toluene 9H-carbazole-9-carbodithioate)}

In our previous study [41], electrogrowth of 9-tosyl$9 \mathrm{H}$-carbazole on the carbon fiber microelectrode (CFME) was studied by $\mathrm{CV}$ at a scan rate of $100 \mathrm{mV} \cdot \mathrm{s}^{-1}$ at different initial monomer concentrations $(1.0,3.0,5.0$ and $10.0 \mathrm{mM})$ in $0.1 \mathrm{M} \mathrm{NaClO}_{4} /$ ACN. The anodic peak potential appeared at $0.78 \mathrm{~V}$ in the initial monomer concentration of $3.0 \mathrm{mM}$, which was a reversible process. When $\mathrm{CS}_{2}$ group included into 9-tosyl-9H-carbazole structure, anodic peak potential was increased from 0.78 to $1.30 \mathrm{~V}$. The peak at $0.97 \mathrm{~V}$ can only be attributed to the redox properties of the polymer $\mathrm{P}(\mathrm{Cz})$, not to carbazole, the monomer as shown in Figure 6 . The total charge of PCz was obtained as $6.128 \mathrm{mC}$ for $8^{\text {th }}$ cycle during electrogrowth process. When tosyl functional group was added to the $\mathrm{Cz}$ structure, it increased the

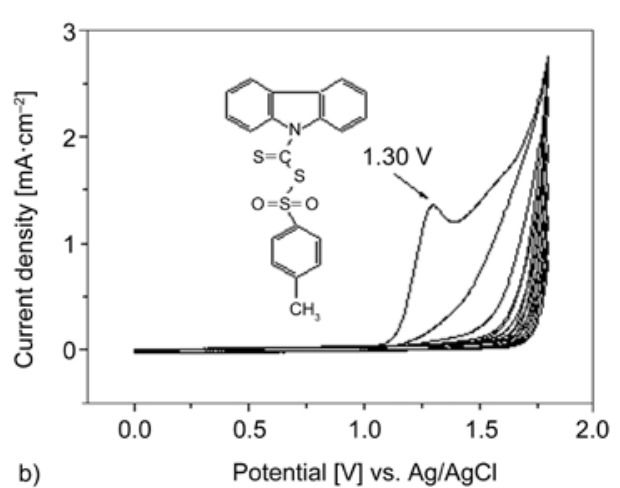

b) 
$Q=9.15 \mathrm{mC}$. However, after addition of $\mathrm{CS}_{2}$ group into the functional tosyl carbazole structure, the total charge decreased to $Q=5.55 \mathrm{mC}$ during electrogrowth process. The main reason of this decrease may be increasing of the length of the carbazole structure. Another important effect of the diffusion and migration of tetrafluoroborate and alkylammonium ions, which has important influence on the EIS. Therefore, $\mathrm{P}(\mathrm{TCzC})$ was difficult to electropolymerize compared to $\mathrm{PCz}$ on GCE.

\subsection{Effect of scan rate in monomer-free solution}

$\mathrm{P}(\mathrm{Cz})$ and $\mathrm{P}(\mathrm{TCzC})$ were immersed into a monomerfree electrolyte solution to check their redox behaviours. Scan rate was an important factor on the polymerization behavior. Modified polymer films were measured at the scan rate of 50, 100, 250, 500 and $1000 \mathrm{mV} \cdot \mathrm{s}^{-1}$ in monomer-free solution. The CVs peak potentials were similar for all scan rates with a small increase in current, which showed the doping and de-doping process of the polymercoated GCE [41]. The peak current density $\left(i_{\mathrm{p}}\right)$ for a reversible voltammogram at $25^{\circ} \mathrm{C}$ is given by the following equation: $i_{\mathrm{p}}=\left(2.69 \cdot 10^{5}\right) \cdot A \cdot D^{1 / 2} \cdot C_{\mathrm{o}} \cdot v^{1 / 2}$ where $v$ is the scan rate. $A$ is the electrode area, $D$ is the diffusion coefficient of electro-active species in the solution [42]. Peak current density is propor- tional $v^{1 / 2}$ in the range of scan rates (Regression fit $\left(R_{\mathrm{An}}=0.99069\right.$ and $\left.R_{\text {Cat }}=-0.98381\right)$ for $\mathrm{P}(\mathrm{Cz})$ and (Regression fit $\left(R_{\mathrm{An}}=0.9982\right.$ and $\left.R_{\mathrm{Cat}}=-0.9972\right)$ for $\mathrm{P}(\mathrm{TCzC}) / \mathrm{GCE}$ where diffusion control applies [43], respectively as given in Figures 7 and 8.

\subsection{FTIR-ATR measurements}

In FTIR-ATR spectrum of $\mathrm{PCz}$ and $\mathrm{P}(\mathrm{TCzC})$ were given in Figures 9 and 10. A significant band at $1090 \mathrm{~cm}^{-1}$ has been attributed to $\mathrm{BF}_{4}^{-}$ion for $\mathrm{P}(\mathrm{Cz})$, which is due to the electrolytes in $\mathrm{TEABF}_{4}$. For the polymer, the band at $1600 \mathrm{~cm}^{-1}$ could be assigned to the anti-symmetric and symmetric $\mathrm{C}-\mathrm{C}$ stretching deformation. The peak at $3400 \mathrm{~cm}^{-1}$ was obtained $\mathrm{N}-\mathrm{H}$ stretching. The peak at 1230 and $720 \mathrm{~cm}^{-1}$ corresponding to stretching of aromatic $\mathrm{C}-\mathrm{N}$ bonds or vibration of disubstituted benzene ring and $-\mathrm{C}-\mathrm{H}$ (out of plane deformation of $\mathrm{C}-\mathrm{H}$ bond in benzene ring. $\mathrm{P}(\mathrm{TCzC})$ corresponds to peak at $3473 \mathrm{~cm}^{-1}$ for $\mathrm{C}-\mathrm{H}$ stretching, at $1626 \mathrm{~cm}^{-1}$ for $\mathrm{C}=\mathrm{C}$ stretching, at $1483 \mathrm{~cm}^{-1}$ for $\mathrm{CH}_{3}$, at $1046 \mathrm{~cm}^{-1}$ for dopant ion $\left(\mathrm{BF}_{4}^{-}\right)$and at $762 \mathrm{~cm}^{-1}$ for $\mathrm{C}-\mathrm{S}$ stretching (Figure 10). The peak at $1156 \mathrm{~cm}^{-1}$ was the bond of $\mathrm{S}=\mathrm{O}$ bond in carbazole structure [44]. In our previous paper, $\mathrm{PCz}$ was electropolymerized on CFME in $0.1 \mathrm{M} \mathrm{NaClO}_{4} / \mathrm{PC}$. A significant band at $1093 \mathrm{~cm}^{-1}$ was attributed to $\mathrm{ClO}_{4}^{-}$ion. Other characteristic peaks at $3559,1626,1233$ and $681-728 \mathrm{~cm}^{-1}$ refer
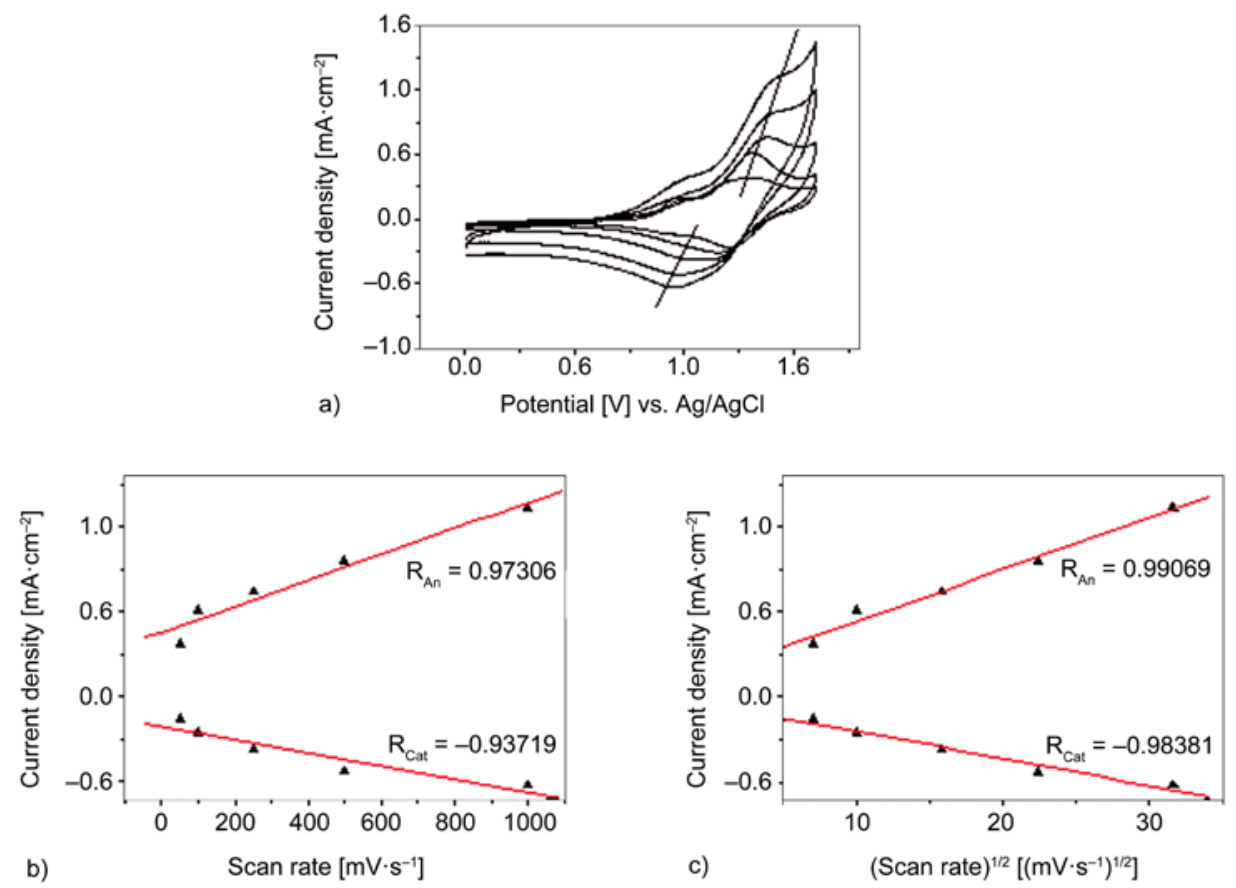

Figure 7. a) $\mathrm{CV}$ of $\mathrm{PCz}$ was obtained at different scan rates in monomer-free solution, b) scan rate vs. Current density, c) square root of scan rate vs. current density plots, $\mathrm{CV}$ was taken as 8 cycle, scan rate: $50-1000 \mathrm{mV} \cdot \mathrm{s}^{-1}$, potential range: $0-1.8 \mathrm{~V}$ in $0.1 \mathrm{M} \mathrm{TEABF}_{4} / \mathrm{CH}_{2} \mathrm{Cl}_{2}-\mathrm{CH}_{3} \mathrm{CN}(8: 2),[\mathrm{Cz}]_{0}=3.0 \mathrm{mM}$. 

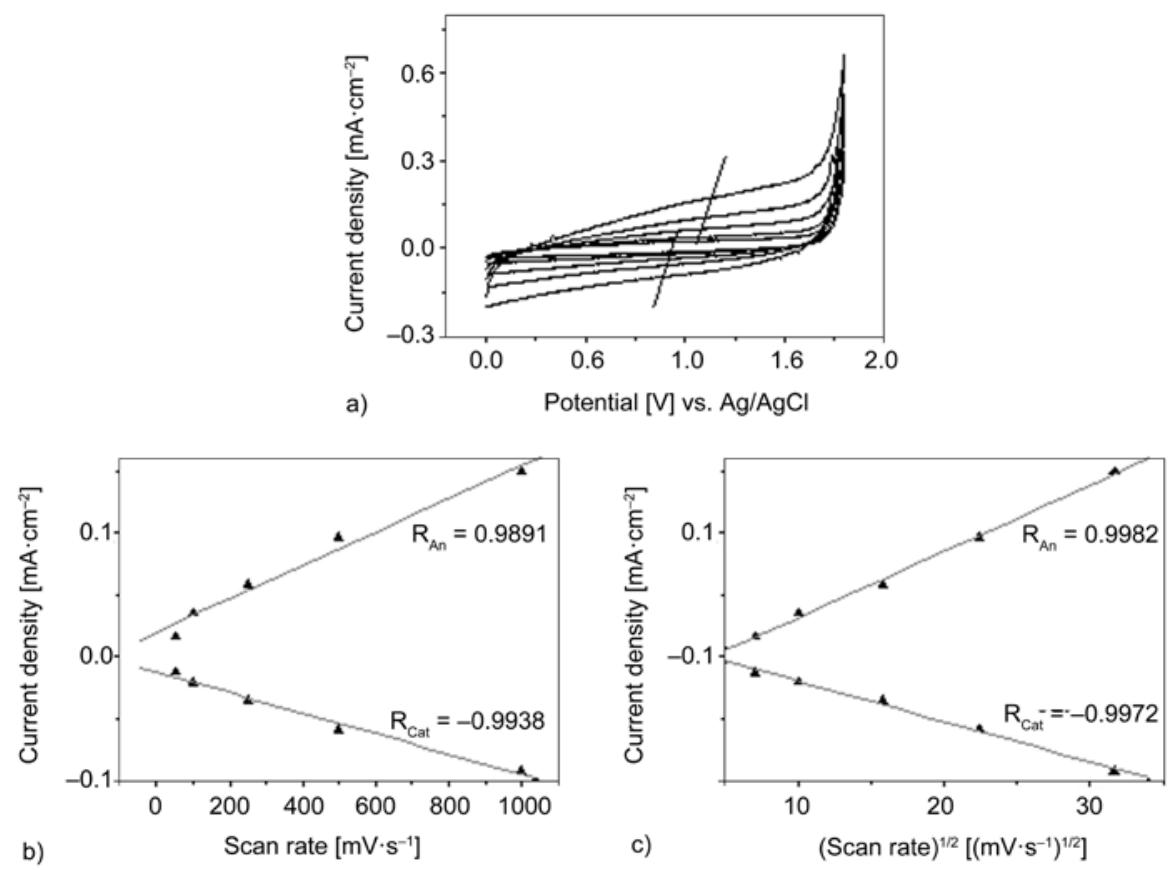

Figure 8. a) $\mathrm{CV}$ of $\mathrm{P}(\mathrm{TCzC})$ was obtained at different scan rates in monomer-free solution, b) scan rate vs. current density, c) square root of scan rate vs. current density plots, 8 cycle, scan rate: $50-1000 \mathrm{mV} \cdot \mathrm{s}^{-1}$, potential range: $0-1.8 \mathrm{~V}$ in $0.1 \mathrm{M} \mathrm{TEABF}_{4} / \mathrm{CH}_{2} \mathrm{Cl}_{2}-\mathrm{CH}_{3} \mathrm{CN}(8: 2),\left[\mathrm{TCzC}_{0}=3.0 \mathrm{mM}\right.$

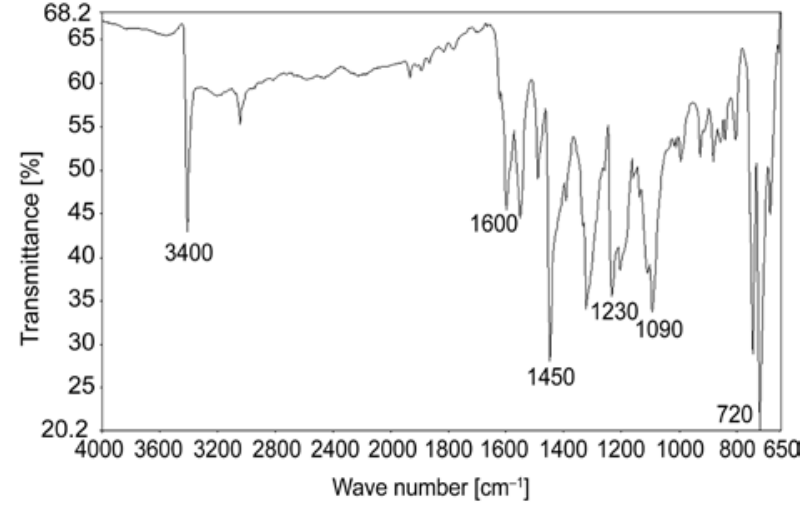

Figure 9. FTIR-ATR spectrum of $\mathrm{P}(\mathrm{Cz}) / \mathrm{CFME}$ in $0.1 \mathrm{M}$ $\mathrm{TEABF}_{4} / \mathrm{CH}_{2} \mathrm{Cl}_{2}-\mathrm{CH}_{3} \mathrm{CN}(8: 2)$

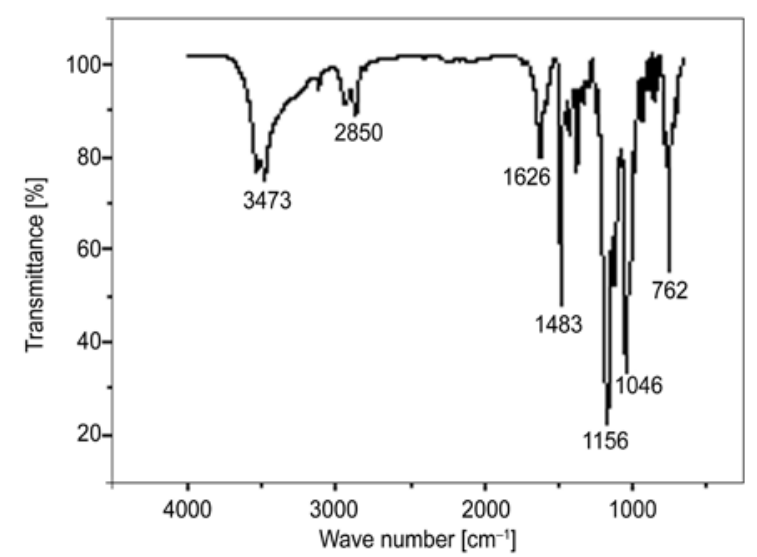

Figure 10. FTIR-ATR spectrum of $\mathrm{P}(\mathrm{TCzC}) / \mathrm{CFME}$ in $0.1 \mathrm{M} \mathrm{TEABF}_{4} / \mathrm{CH}_{2} \mathrm{Cl}_{2}-\mathrm{CH}_{3} \mathrm{CN}(8: 2)$ to $-\mathrm{CH}_{3}$ ( $\mathrm{sp}^{3} \mathrm{CH}$ str.), the anti-symmetric and symmetric $\mathrm{C}=\mathrm{C}$ str. Deformation, $-\mathrm{C}-\mathrm{N}$ (str. of aromatic $\mathrm{C}-\mathrm{N}$ bonds or vibrational of disubstituted benzene ring) and $\mathrm{C}-\mathrm{H}$ (out of plane deformation of $\mathrm{C}-\mathrm{H}$ bond in benzene ring) [45], respectively. $\mathrm{PCz}$ and $\mathrm{P}(\mathrm{TCzC})$ have different characteristic peaks to differentiate the functionality of polycarbazole.

\subsection{SEM and AFM measurements}

SEM micrograph of $\mathrm{P}(\mathrm{TCzC}) / \mathrm{CFME}$ was shown in Figure 11. Polymerization was performed on a single CFME (with diameter approximately $0.022 \mathrm{~cm}^{2}$ ). Some pores of granules were shown on the CFME.

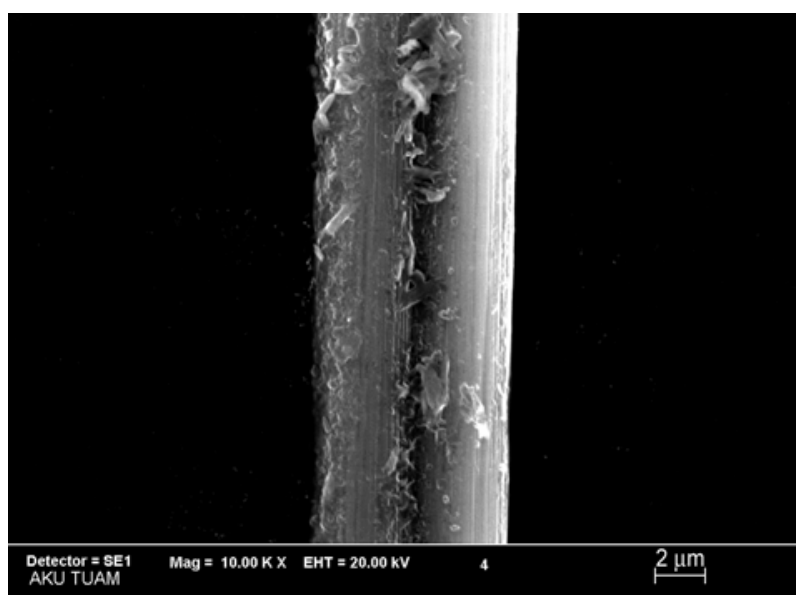

Figure 11. SEM images of $\mathrm{P}(\mathrm{TCzC}) / \mathrm{CFME}$ was performed in $0.1 \mathrm{M} \mathrm{TEABF} 4 / \mathrm{CH}_{2} \mathrm{Cl}_{2}-\mathrm{CH}_{3} \mathrm{CN}$ (8:2) while the electropolymerization was carried out 

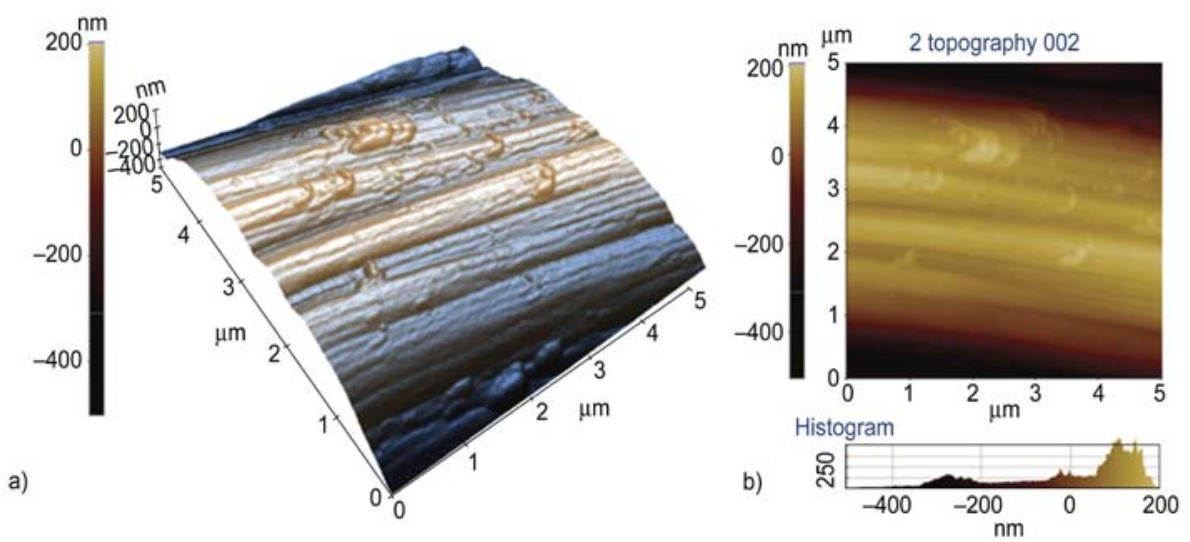

Figure 12. AFM analysis of $\mathrm{P}(\mathrm{TCzC}) / \mathrm{CFME}$ was performed in $0.1 \mathrm{M} \mathrm{TEABF} / \mathrm{CH}_{2} \mathrm{Cl}_{2}-\mathrm{CH}_{3} \mathrm{CN}(8: 2)$ while the electropolymerization was carried out

AFM images of $\mathrm{P}(\mathrm{TCzC}) / \mathrm{CFME}$ were obtained by fixing the fiber on a piece of silicon wafer with resin as shown in Figure 12. The AFM average roughness $\left(R_{\mathrm{q}}\right)$ value was obtained as $248.6 \mathrm{~nm}$. AFM images of $\mathrm{P}(\mathrm{TCzC})$ was given in Figure 12. The electro-coating of modified electrodes was observed with granules on CFME. It was found in our previous study [46] from the cross-sectional analyses that striations of uncoated CFME with approximately $1 \mu \mathrm{m}$ depth started disappearing and lower a thickness value of $50 \mathrm{~nm}$. There is no doubt that average roughness value of uncoated CFME was increased $\sim 5$ times by electro-coating process. It is strong evidence of successful polymer formation provided by AFM analysis.

\subsection{Electrochemical impedance spectroscopic study}

Among electrochemical characterization techniques EIS represented useful results for the investigation of conducting polymers due to the small perturbations involved in the operative conditions for the impedance measurements $[47,48]$. The impedance measurements, resistance was the real part and capacitance was calculated as $C=-1 /\left(2 \pi f Z^{\prime \prime}\right)$, where $\pi=$ $3.14, f$ was frequency in $\mathrm{Hz}$, and $Z^{\prime \prime}$ was the imaginary part of the impedance [49]. The low frequency capacitances $(10 \mathrm{mHz})$ of $\mathrm{P}(\mathrm{Cz})\left(C_{\mathrm{LF}}=1.44 \mathrm{mF} \cdot \mathrm{cm}^{-2}\right)$ and $\mathrm{P}(\mathrm{TCzC}) / \mathrm{GCE}\left(C_{\mathrm{LF}}=0.43 \mathrm{mF} \cdot \mathrm{cm}^{-2}\right)$ were taken to identify the specific capacitance of polymer modified films. For lower frequencies, the spectra approached a nearly vertical line in the complex plane, which was typical of an ideal capacitor behavior. $C_{\mathrm{LF}}$ value decreased of 3.34 times by addition of $\mathrm{CS}_{2}$ and tosyl group into the carbazole monomer (Figure 13a). In the Bode-phase plot, the maximum phase angle was obtained as $\sim 65^{\circ}$ at the frequency of $\sim 5 \mathrm{~Hz}$ as given in Figure 13b. The maximum capacitance value of $\mathrm{P}(\mathrm{TCzC}) / \mathrm{GCE}$ was obtained as $\sim 37 \mu \mathrm{F}$ as shown in Figure 13c.

The model circuit comprised of eight elements, the solution resistance $\left(R_{\mathrm{S}}\right)$ was in series with the electrical double layer capacitance $\left(C_{\mathrm{dl}}\right)$ at the electrode and electrolyte. $C_{\mathrm{dl}}$ was in parallel with $R_{1}$ and $\left(R_{2}\right.$, $W$, and $Q$ ). The Warburg impedance was associated with the semi-infinite diffusion of ions in the electrode $[50,51]$. The values of circuit parameters were estimated qualitatively from the fittings of experimental impedance spectra and presented for $\mathrm{PCz} / \mathrm{GCE}$ in Table 1 and $\mathrm{P}(\mathrm{TCzC}) / \mathrm{GCE}$ in Table 2. The mean error of the modulus was $\sim 10 \%$. The chisquared $\left(\chi^{2}\right)$ was obtained as $10^{-3}$ and $10^{-4}$ for the circuit evaluations. $\chi^{2}$ was the function defined as the sum of the squares of the residuals.

In literature, capacitors and supercapacitors are modeled by using many simple $R C$ circuits. However, these models cannot accurately describe the voltage behavior of the modified polymer film and elec-

Table 1. Electrical equivalent circuit model of $R(C(R(Q(R W))))(C R)$, which is obtained for $\mathrm{PCz} / \mathrm{GCE}$

\begin{tabular}{|l|c|c|c|c|}
\hline \multirow{2}{*}{$\begin{array}{c}\text { Circuit } \\
\text { components }\end{array}$} & \multicolumn{4}{|c|}{ DC potential for PCz/GCE } \\
\cline { 2 - 5 } & $\mathbf{- 0 . 1} \mathbf{~ V}$ & $\mathbf{0 . 1} \mathbf{~ V}$ & $\mathbf{0 . 5} \mathbf{~ V}$ & $\mathbf{1 . 0} \mathbf{~ V}$ \\
\hline$R_{\mathrm{S}}[\Omega]$ & 360.7 & 313.0 & 300.3 & 313.2 \\
\hline$C_{\mathrm{dl}}[\mu \mathrm{F}]$ & 2.24 & 1.61 & $4.54 \cdot 10^{-2}$ & $6.21 \cdot 10^{-2}$ \\
\hline$R_{1}[\Omega]$ & 560.4 & 142.9 & 40.3 & 5.29 \\
\hline$Q\left[\mu \mathrm{S} \cdot \mathrm{s}^{\mathrm{n}}\right]$ & 12.6 & 16.0 & 18.8 & 12.4 \\
\hline$n$ & 0.76 & 0.80 & 0.71 & 0.74 \\
\hline$R_{2}[\Omega]$ & $1.29 \cdot 10^{5}$ & $7.08 \cdot 10^{4}$ & $3.18 \cdot 10^{4}$ & 202.3 \\
\hline$W\left[\mu \mathrm{S} \cdot \mathrm{s}^{-\mathrm{n}}\right]$ & 18.0 & 36.8 & 144.0 & 21.7 \\
\hline$C_{\mathrm{GCE}}[\mu \mathrm{F}]$ & 0.624 & 0.041 & 43.5 & 0.94 \\
\hline$R_{\mathrm{GCE}}[\Omega]$ & 48.0 & 38.6 & 9924.0 & 1068.0 \\
\hline$\chi^{2}$ & $5.54 \cdot 10^{-4}$ & $9.02 \cdot 10^{-4}$ & $3.28 \cdot 10^{-4}$ & $2.04 \cdot 10^{-3}$ \\
\hline
\end{tabular}



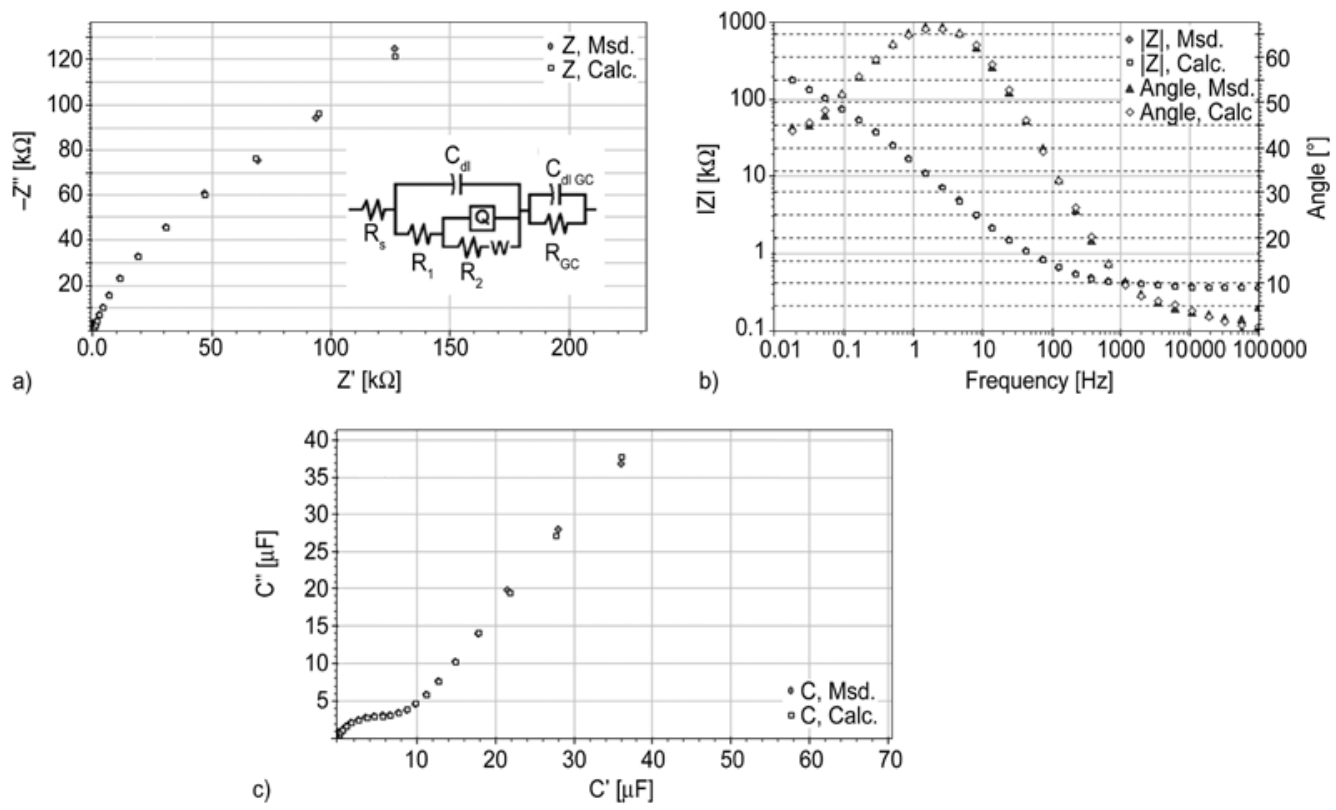

Figure 13. a) Nyquist graph inset: electrical equivalent circuit model of $R(C(R(Q(R W))))(C R)$, b) Bode magnitude and Bode-phase plot, c) capacitance graph of poly (TCzC) obtained by simulation ZSimpWin 3.10 program. Experiments were performed by simulation as the following conditions. $[\mathrm{TCzC}]_{0}=3.0 \mathrm{mM}, 0.1 \mathrm{M} \mathrm{TEABF} /$ $\mathrm{CH}_{2} \mathrm{Cl}_{2}-\mathrm{CH}_{3} \mathrm{CN}$ (8:2). Potential range was taken from 0 to1.8 V.

Table 2. Electrical equivalent circuit model of $R(C(R(Q(R W))))(C R)$, which is obtained for $\mathrm{P}(\mathrm{TCzC}) / \mathrm{GCE}$

\begin{tabular}{|l|c|c|c|c|}
\hline \multirow{2}{*}{$\begin{array}{c}\text { Circuit } \\
\text { components }\end{array}$} & \multicolumn{4}{|c|}{ DC Potential for P(TCzC)/GCE } \\
\cline { 2 - 5 } & $\mathbf{- 0 . 1} \mathbf{~ V}$ & $\mathbf{0 . 1} \mathbf{~ V}$ & $\mathbf{0 . 5} \mathbf{~ V}$ & $\mathbf{1 . 0} \mathbf{~ V}$ \\
\hline$R_{\mathrm{S}}[\Omega]$ & 381.8 & 216.0 & 342.2 & 330.8 \\
\hline$C_{\mathrm{dl}}[\mu \mathrm{F}]$ & 0.87 & 0.46 & 0.67 & 0.69 \\
\hline$R_{1}[\Omega]$ & 0.01 & 144.5 & 62.4 & 0.09 \\
\hline$Q\left[\mu \mathrm{S} \cdot \mathrm{s}^{\mathrm{n}}\right]$ & 4.39 & 1.75 & 5.80 & 18.9 \\
\hline$n$ & 0.48 & 0.82 & 0.79 & 0.89 \\
\hline$R_{2}[\Omega]$ & $3.82 \cdot 10^{6}$ & $7.53 \cdot 10^{4}$ & $1.47 \cdot 10^{5}$ & 0.037 \\
\hline$W\left[\mu \mathrm{S} \cdot \mathrm{s}^{-\mathrm{n}}\right]$ & 252.0 & 5.48 & 18.2 & 34.7 \\
\hline$C_{\mathrm{GCE}}[\mu \mathrm{F}]$ & 1.41 & 1.35 & 19.1 & 8.75 \\
\hline$R_{\mathrm{GCE}}[\Omega]$ & 67.4 & 147.0 & 3734.0 & 1026.0 \\
\hline$\chi^{2}$ & $1.06 \cdot 10^{-3}$ & $3.65 \cdot 10^{-4}$ & $3.14 \cdot 10^{-4}$ & $2.47 \cdot 10^{-3}$ \\
\hline
\end{tabular}

trolyte system $[52,53]$. For fitting the data all capacitances in the equivalent circuit model of $R(C(R(Q(R W))))(C R)$ had to be replaced by a constant phase element $\mathrm{CPE}$ or $Q\left[Z_{\mathrm{CPE}}=A_{\mathrm{CPE}}(j w)^{-\mathrm{n}}\right]$ in order to adopt for non ideal behavior [54]. If $n=1$ then $1 / A_{\mathrm{CPE}}=C$ with the dimension $\mathrm{F} \cdot \mathrm{cm}^{-2}$. The value of an ideal capacitance can be determined from the Bode plot of the impedance by extraploting the measured capacitance with the slope $-n$ to the frequency $f=1000 \mathrm{~Hz}$ [55]. The highest $n$ value of $\mathrm{PCz}$ was obtained as 0.80 at the DC potential of $0.1 \mathrm{~V}$ by applying EIS measurement. However, there were values as 0.82 and 0.89 for $\mathrm{P}(\mathrm{TCzC}) / \mathrm{GCE}$ system at the potential of 0.1 and $1.0 \mathrm{~V}$, respectively. The highest double layer capacitance $\left(C_{\mathrm{dl}}\right)$ was obtained as

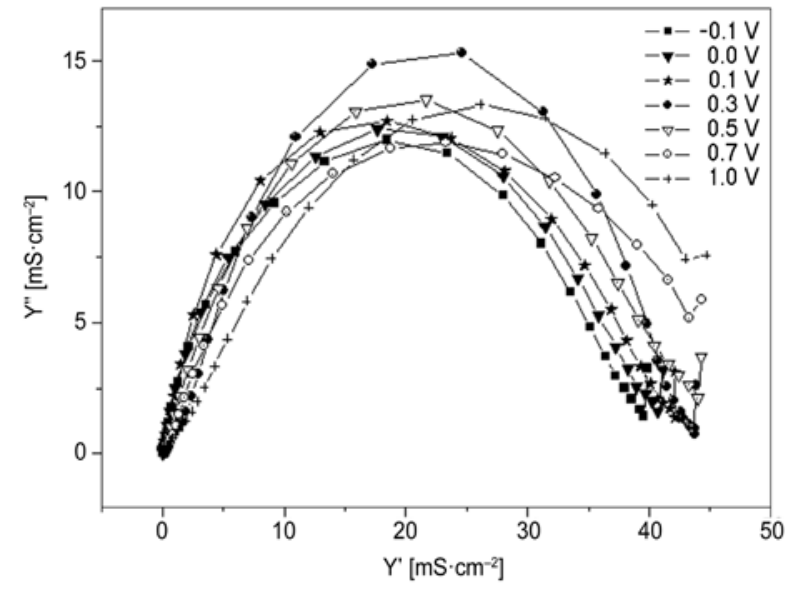

Figure 14. Admittance graph of $\mathrm{P}(\mathrm{TCzC})$ obtained by different $\mathrm{DC}$ potentials from -0.1 to $1.0 \mathrm{~V}$. $[\mathrm{TCzC}]_{0}=$ $3.0 \mathrm{mM}, 0.1 \mathrm{M} \mathrm{TEABF}_{4} / \mathrm{CH}_{2} \mathrm{Cl}_{2}-\mathrm{CH}_{3} \mathrm{CN}$ (8:2). Potential range was taken from 0 to $1.8 \mathrm{~V}$.

$2.24 \mu \mathrm{F}$ for $\mathrm{PCz}$ and $0.87 \mu \mathrm{F}$ for $\mathrm{P}(\mathrm{TCzC}) / \mathrm{GCE}$ at the DC potential of -0.1 V. $R_{1}$ and $R_{2}$ values decrease by increasing of DC potential of PCz. However, there was no systematic relation of $\mathrm{P}(\mathrm{TCzC}) / \mathrm{GCE}$. The highest $R_{1}=144.5 \Omega$ at the DC potential of $0.1 \mathrm{~V}$. However, $R_{2}=3.82 \mathrm{M} \Omega$ at the DC potential of $-0.1 \mathrm{~V}$.

The highest conductivity of $\mathrm{P}(\mathrm{TCzC}) / \mathrm{GCE}$ was obtained at the $\mathrm{DC}$ potential of $0.3 \mathrm{~V}$ for $\mathrm{P}(\mathrm{TCzC}) /$ GCE as shown in Figure 14. There was an order from $\mathrm{DC}$ potential from -0.1 to $1.0 \mathrm{~V}$. There was a deviation of $0.3 \mathrm{~V}$ for the $\mathrm{P}(\mathrm{TCzC}) / \mathrm{GCE}$. 


\section{Conclusions}

EIS was employed to characterize the capacitive behavior of electrochemically prepared novel synthesis of $\mathrm{P}(\mathrm{TCzC})$ film electrodes in organic electrolytes. The changing of polymer capacitance in dependence of the potential range from -0.1 to $1.0 \mathrm{~V}$ for $\mathrm{PCz}$ and $\mathrm{P}(\mathrm{TCzC}) / \mathrm{GCE}$. $C_{\mathrm{dl}}$ was obtained as $2.24 \mu \mathrm{F}$ for $\mathrm{PCz}$ and $0.87 \mu \mathrm{F}$ for $\mathrm{P}(\mathrm{TCzC}) / \mathrm{GCE}$ at the $\mathrm{DC}$ potential of $-0.1 \mathrm{~V}$. And the resistance of GCE was obtained as $R_{\mathrm{GCE}}=9924 \Omega$ for $\mathrm{PCz}$ and $R_{\mathrm{GCE}}=3734 \Omega$ for $\mathrm{P}(\mathrm{TCzC})$ at the $\mathrm{DC}$ potential of $0.5 \mathrm{~V}$. The double layer capacitance of $\mathrm{P}(\mathrm{TCzC})$ was lower than $\mathrm{PCz}$. $\mathrm{CS}_{2}$ group with tosyl group into $\mathrm{Cz}$ monomer decreased the capacitor behavior of the polymer.

\section{Acknowledgements}

This work was supported by The Scientific \& Technological Council of Turkey (TUBITAK)-TBAG-110T791 Project. Authors also thank to Yakup Bakis (Fatih University, BINATAM, Istanbul, Turkey) for recording AFM images.

\section{References}

[1] Gupta B., Singh A. K., Prakash R.: Electrolyte effects on various properties of polycarbazole. Thin Solid Films, 519, 1016-1019 (2010).

DOI: $10.1016 /$ j.tsf.2010.08.034

[2] Inzelt Gy.: Formation and redox behaviour of polycarbazole prepared by electropolymerization of solid carbazole crystals immobilized on an electrode surface. Journal of Solid State Electrochemistry, 7, 503-510 (2003).

DOI: $10.1007 / \mathrm{s} 10008-003-0357-0$

[3] Du Y., Shen S. Z., Cai K. F., Casey P. S.: Research progress on polymer-inorganic thermoelectric nanocomposite materials. Progress in Polymer Science, 37, 820-841 (2012).

DOI: $10.1016 /$ j.progpolymsci.2011.11.003

[4] Deng J., Guo L., Xiu Q., Zhang L., Wen G., Zhong C.: Two polymeric metal complexes based on polycarbazole containing complexes of 8-hydroxyquinoline with $\mathrm{Zn}(\mathrm{II})$ and $\mathrm{Ni}(\mathrm{II})$ in the backbone: Synthesis, characterization and photovoltaic applications. Materials Chemistry and Physics, 133, 452-458 (2012).

DOI: 10.1016/j.matchemphys.2012.01.064

[5] Bussiére P-O., Rivaton A., Thérias S., Gardette J-L.: Multiscale investigation of the poly $(N$-vinylcarbazole $)$ photoageing mechanism. Journal of Physical Chemistry B, 116, 802-812 (2012).

DOI: $10.1021 / j p 211358 \mathrm{q}$
[6] Ates M., Uludag N., Karazehir T.: Copolymer formation of 9-(2-(benzyloxy)ethyl)-9H-carbazole and 1tosyl- $1 H$-pyrrole coated on glassy carbon electrode and electrochemical impedance spectroscopy. Journal of Solid State Electrochemistry, 16, 2639-2649 (2012). DOI: $10.1007 / \mathrm{s} 10008-012-1688-5$

[7] Stolar M., Baumgartner T.: Synthesis and unexpected halochromism of carbazole-functionalized dithienophospholes. New Journal of Chemistry, 36, 1153-1160 (2012). DOI: $10.1039 / \mathrm{c} 2 \mathrm{nj} 40022 \mathrm{~g}$

[8] Gupta B., Joshi L., Prakash R.: Novel synthesis of polycarbazole-gold nanocomposite. Macromolecular Chemistry and Physics, 212, 1692-1699 (2011). DOI: $10.1002 / \mathrm{macp} .201100262$

[9] Li S., Zhuang L-Q., George T. F.: Electric field-tuned polymer amplified spontaneous emission. Journal of the Electrochemical Society, 159, P29-P34 (2012). DOI: $10.1149 / 2.001203$ jes

[10] Pawar S. G., Chougule M. A., Sen S., Patil V. B.: Development of nanostructured polyaniline-titanium dioxide gas sensors for ammonia recognition. Journal of Applied Polymer Science, 125, 1418-1424 (2012). DOI: $10.1002 /$ app.35468

[11] Booth M. A., Harbison S., Travas-Sejdic J.: Effects of redox couple on the response of polypyrrole-based electrochemical DNA Sensors. Electroanalysis, 24, 1311-1317 (2012).

DOI: 10.1002/elan.201200119

[12] Drelinkiewicz A., Zięba A., Solbezak J. W., Bonarawska M., Karpiński Z., Walksmundzka-Góra A., Stejskal J.: Polyaniline stabilized highly dispersed Pt nanoparticles: Preparation, characterization and catalytic properties. Reactive and Functional Polymers, 69, 630-642 (2009).

DOI: $10.1016 /$ j.reactfunctpolym.2009.04.007

[13] Nie G., Xu J., Zhang S., Cai T., Han X.: Electrochemical copolymerization of carbazole and 3-methylthiophene. Journal of Applied Polymer Science, 102, 18771885 (2006).

DOI: $10.1002 / a p p .24157$

[14] Huang M-R., Lu H-J., Li X-G.: Synthesis and strong heavy-metal ion sorption of copolymer microparticles from phenylenediamine and its sulfonate. Journal of Materials Chemistry, 22, 17685-17699 (2012).

DOI: $10.1039 / \mathrm{c} 2 \mathrm{jm} 32361 \mathrm{c}$

[15] Li X-G., Feng H., Huang M-R., Gu G-L., Moloney M. G.: Ultrasensitive $\mathrm{Pb}(\mathrm{II})$ potentiometric sensor based on copolyaniline nanoparticles in a plasticizer-free membrane with a long lifetime. Analytical Chemistry, 84, 134-140 (2012). DOI: $10.1021 / \mathrm{ac} 2028886$

[16] Li X-G., Lü Q-F., Huang M-R.: Self-stabilized nanoparticles of intrinsically conducting copolymers from 5-sulfonic-2-anisidine. Small, 4, 1201-1209 (2008).

DOI: $10.1002 / \mathrm{smll} .200701002$ 
[17] Ates M., Uludag N., Karazehir T., Arican F.: A novel synthesis of 3,6-bis(2,3-dihydrothieno[3,4-b][1,4]dioxin5-yl)-9-tosyl-9H-carbazole. Ovidius University Annals of Chemistry, 23, 63-71 (2012).

DOI: $10.2478 / \mathrm{v} 10310-012-0010-9$

[18] Uludag N., Ates M., Tercan B., Hökelek T.: 5-(3,6dibromo-9H-carbazol-9-yl)pentanenitrile. Acta Crystallographica Section E: Structure Report Online, 67, o642 (2011).

DOI: $10.1107 / \mathrm{S} 1600536811005162$

[19] Ates M., Uludag N., Sarac A. S.: Synthesis and electropolymerization of 9-tosyl-9H-carbazole, electrochemical impedance spectroscopic study and circuit modelling. Fibers and Polymers, 12, 8-14 (2011).

DOI: $10.1007 / \mathrm{s} 12221-011-0008-5$

[20] Ates M., Uludag N., Sarac A. S.: Electrochemical impedance of poly(9-tosyl-9H-carbazole-co-pyrrole) electrocoated carbon fiber. Materials Chemistry and Physics, 127, 120-127 (2011).

DOI: 10.1016/j.matchemphys.2011.01.050

[21] Lee H-Y, Chen G. S., Chen C-S., Chern J-W.: Efficient microwave-assisted synthesis of ellipticine through $N$ (1,4-dimethyl-9H-carbazol-3-ylmethyl)- $N$-tosylaminoacetaldehyde diethyl acetal. Journal of Heterocyclic Chemistry, 47, 454-458 (2010).

DOI: $10.1002 /$ jhet.319

[22] Hökelek T., Dal H., Tercan B., Gülle S., Ergün Y.: Ethyl 4-hydroxy-9-tosyl-9H-carbazole-3-carboxylate. Acta Crystallographica Section E: Structure Reports Online, 65, o1515-o1516 (2009).

DOI: $10.1107 / \mathrm{S} 1600536809021035$

[23] Gu Y., Chen W-Q., Wada T., Hashizume D., Duan XM.: From supermolecular sheet to helix by breaking molecular symmetry: the case of 4-[2-(carbazol-3-yl) vinyl] pyridium tosylate. CrystEngComm, 9, 541-544 (2007).

DOI: $10.1039 / \mathrm{b} 701377 \mathrm{a}$

[24] Martinez-Esperón M. F., Rodríquez D., Castedo L., Saá C.: Coupling and cycloaddition of ynamides: homoand Negishi coupling of tosylynamides and intramolecular [4+2] cycloaddition of $N$-(o-ethynyl)phenyl ynamides and arylynamides. Tetrahedron, 62, 38433855 (2006).

DOI: $10.1016 /$ j.tet.2005.11.082

[25] Ates M., Uludag N.: Synthesis of 9-(4-nitrophenylsulfonyl)-9H-carbazole: Comparison of an impedance study of poly[9-(4-nitrophenylsulfonyl)-9H-carbazole] on gold and carbon fiber microelectrodes. Journal of Applied Polymer Science, 124, 4655-4662 (2012). DOI: $10.1002 /$ app.35380

[26] Beaujuge P. M., Reynolds J. R.: Color control in $\pi$-conjugated organic polymers for use in electrochromic devices. Chemical Reviews, 110, 268-320 (2010). DOI: $10.1021 / \mathrm{cr} 900129 \mathrm{a}$

[27] Kötz R., Hahn M., Gallay R.: Temperature behavior and impedance fundamentals of supercapacitors. Journal of Power Sources, 154, 550-555 (2006).

DOI: $10.1016 /$ j.jpowsour.2005.10.048
[28] Vorotyntsev M. A., Daikhin L. I., Levi M. D.: Modelling the impedance properties of electrodes coated with electroactive polymer films. Journal of Electroanalytical Chemistry, 364, 37-49 (1994). DOI: 10.1016/0022-0728(93)02957-J

[29] Inzelt G., Pineri M., Schultze J. W., Vorotyntsev M. A.: Electron and proton conducting polymers: recent developments and prospects. Electrochimica Acta, 45, 24032421 (2000).

DOI: $10.1016 / \mathrm{S} 0013-4686(00) 00329-7$

[30] Aravinda L. S., Bhat K. U., Bhat B. R.: Nano $\mathrm{CeO}_{2} /$ activated carbon based composite electrodes for high performance supercapacitor. Materials Letters, 112, 158-161 (2013).

DOI: $10.1016 /$ j.matlet.2013.09.009

[31] Yang J. E., Jang I., Kim M., Baeck S. H., Hwang S., Shim S. E.: Electrochemically polymerized vine-like nanostructured polyaniline on activated carbon nanofibers for supercapacitor. Electrochimica Acta, 111, 136-143 (2013).

DOI: 10.1016/j.electacta.2013.07.183

[32] Zhang L. L., Zhao X. S.: Carbon-based materials as supercapacitor electrodes. Chemical Society Reviews, 38, 2520-2531 (2009). DOI: $10.1039 / \mathrm{b} 813846 \mathrm{j}$

[33] Li C., Wang D., Liang T., Wang X., Ji L.: A study of activated carbon nanotubes as double-layer capacitors electrode materials. Materials Letters, 58, 3774-3777 (2004).

DOI: 10.1016/j.matlet.2004.07.027

[34] Hwang S-G., Ryu S-H., Yun S-R., Ko J. M., Kim K. M., Ryu K-S.: Behavior of NiO- $\mathrm{MnO}_{2} / \mathrm{MWCNT}$ composites for use in a supercapacitor. Materials Chemistry and Physics, 130, 507-512 (2011).

DOI: $10.1016 /$ j.matchemphys.2011.07.022

[35] Kuang H., Cao Q., Wang X., Jing B., Wang Q., Zhou L.: Influence of the reaction temperature on polyaniline morphology and evaluation of their performance as supercapacitor electrode. Journal of Applied Polymer Science, 130, 3753-3758 (2013).

DOI: $10.1002 / a p p .39650$

[36] He X., Gao B., Wang G., Wei J., Zhao C.: A new nanocomposite: Carbon cloth based polyaniline for an electrochemical supercapacitor. Electrochimica Acta, 111, 210-215 (2013).

DOI: 10.1016/j.electacta.2013.07.226

[37] Lu T., Zhang Y., Li H., Pan L., Li Y., Sun Z.: Electrochemical behaviors of graphene- $\mathrm{ZnO}$ and graphene$\mathrm{SnO}_{2}$ composite films for supercapacitors. Electrochimica Acta, 55, 4170-4173 (2010). DOI: $10.1016 /$ j.electacta.2010.02.095

[38] Zhi M., Xiang C., Li J., Li M., Wu N.: Nanostructured carbon-metal oxide composite electrodes for supercapacitors: A review. Nanoscale, 5, 72-88 (2013).

DOI: $10.1039 / \mathrm{c} 2 \mathrm{nr} 32040 \mathrm{a}$ 
[39] Zhou D., Zhu X. L., Zhu J., Yin H. S.: Influence of the chemical structure of dithiocarbamates with different $\mathrm{N}$-groups on the reversible addition-fragmentation chain transfer polymerization of styrene. Journal of Polymer Science Part A: Polymer Chemistry, 43, 4849-4856 (2005).

DOI: $10.1002 /$ pola.20947

[40] Xue X., Zhu J., Zhang Z., Cheng Z., Tu Y., Zhu X.: Synthesis and characterization of azobenzene-functionalized poly(styrene)- $b$-poly(vinyl acetate) via the combination of RAFT and 'click' chemistry. Polymer, 51, 3083-3090 (2010). DOI: 10.1016/j.polymer.2010.04.052

[41] Sarac A. S., Evans U., Serantoni M., Cunnane V. J.: Electrochemical and morphological study of the effect of polymerization conditions on poly(tetrathiophene) with emphasis on carbon fiber microelectrodes: A cyclic voltammetry and atomic force microscopy study. Carbon, 41, 2725-2730 (2003).

DOI: $10.1016 / \mathrm{S} 0008-6223(03) 00331-2$

[42] Sarac A. S., Ates M., Parlak E. A.: Electrolyte and solvent effects of electrocoated polycarbazole thin films on carbon fiber microelectrodes. Journal of Applied Electrochemistry, 36, 889-898 (2006).

DOI: $10.1007 / \mathrm{s} 10800-006-9145-8$

[43] Rusling J. F., Suib S. L.: Characterizing materials with cyclic voltammetry. Advanced Materials, 6, 922-930 (1994). DOI: 10.1002/adma.19940061204

[44] Sarac A. S., Sezgin S., Ates M., Turhan C. M.: Electrochemical impedance spectroscopy and morphological analyses of pyrrole, phenylpyrrole and methoxyphenylpyrrole on carbon fiber microelectrodes. Surface and Coatings Technology, 202, 3997-4005 (2008). DOI: $10.1016 /$ j.surfcoat.2008.02.007

[45] Papež V., Inganäs O., Cimrová V., Nešpůrek S.: Electrochemical preparation and study of thin $\operatorname{poly}(\mathrm{N}$ vinylcarbazole) layers. Journal of Electroanalytical Chemistry and Interfacial Electrochemistry, 282, 123139 (1990).

DOI: 10.1016/0022-0728(91)85093-5

[46] Sarac A. S., Sezgin S., Ates M., Turhan M. C.: Monomer concentration effect on electrochemically modified carbon fiber with poly[1-(4-methoxyphenyl)$1 H$-pyrrole] as microcapacitor electrode. Advances in Polymer Technology, 28, 120-130 (2009).

DOI: $10.1002 / \mathrm{adv} .20152$
[47] Musiani M. M.: Characterization of electroactive polymer layers by electrochemical impedance spectroscopy (EIS). Electrochimica Acta, 35, 1665-1670 (1990).

DOI: $10.1016 / 0013-4686(90) 80023-\mathrm{H}$

[48] Tarola A., Dini D., Salatelli E., Andreani F., Decker F.: Electrochemical impedance spectroscopy of polyalkylterthiophenes. Electrochimica Acta, 44, 4189-4193 (1999).

DOI: 10.1016/S0013-4686(99)00133-4

[49] Miller J. R., Outlaw R. A., Holloway B. C.: Graphene electric double layer capacitor with ultra-high-power performance. Electrochimica Acta, 56, 10443-10449 (2011).

DOI: $10.1016 /$ j.electacta.2011.05.122

[50] Sen P., De A.: Electrochemical performances of poly(3,4-ethylenedioxythiophene)- $\mathrm{NiFe}_{2} \mathrm{O}_{4}$ nanocomposite as electrode for supercapacitor. Electrochimica Acta, 55, 4677-4684 (2010).

DOI: $10.1016 /$ j.electacta.2010.03.077

[51] Conway B. E.: Electrochemical supercapacitors, scientific fundamantals and technological applications. Kluwer Academic/Plenum Publishers, New York (1999).

[52] Mahon P. J, Paul G. L., Keshishian S. M., Vassallo A. M.: Measurement and modelling of the high-power performance of carbon-based supercapacitors. Journal of Power Sources, 91, 68-76 (2000). DOI: $10.1016 / \mathrm{S} 0378-7753(00) 00488-2$

[53] Buller S., Karden E., Kok D., De Donker R. W.: Modeling the dynamic behavior of supercapacitors using impedance spectroscopy. IEEE Transactions on Industry Applications, 38, 1622-1626 (2002). DOI: $10.1109 /$ TIA.2002.804762

[54] Rammelt U., Reinhard G.: On the applicability of a constant phase element (CPE) to the estimation of roughness of solid metal electrodes. Electrochimica Acta, 35, 1045-1049 (1990).

DOI: $10.1016 / 0013-4686(90) 90040-7$

[55] Fikus A., Rammelt U., Plieth W.: Characterization of semiconductor properties of polybithiophene film electrodes in contact with aqueous electrolytes. A combination of electrochemical impedance spectroscopy and photocurrent measurements. Electrochimica Acta, 44, 2025-2035 (1999). DOI: $10.1016 / \mathrm{S} 0013-4686(98) 00311-9$ 